\title{
Detection of mutations in the insulin receptor gene in patients with insulin resistance by analysis of single-stranded conformational polymorphisms
}

\author{
H.Kim ${ }^{1}$, H.Kadowaki ${ }^{2}$,H.Sakura ${ }^{1}$, M.Odawara ${ }^{1}$, K.Momomura ${ }^{1}$,Y.Takahashi ${ }^{1}$, Y.Miyazaki ${ }^{3}$, T.Ohtani ${ }^{4}$, \\ Y. Akanuma ${ }^{2}$, Y. Yazaki ${ }^{1}$, M. Kasuga ${ }^{5}$, S. I. Taylor ${ }^{6}$ and T. Kadowaki ${ }^{1,2}$ \\ 1 The Third Department of Internal Medicine, Faculty of Medicine, University of Tokyo, \\ ${ }^{2}$ Institute for Diabetes Care and Research, Asahi Life Foundation, \\ ${ }^{3}$ Misato Kenwa Hospital, Misato, \\ ${ }^{4}$ Department of Pediatrics, Tokyo Women's Medical College, Tokyo, \\ 5 The Second Department of Internal Medicine, Faculty of Medicine, Kobe University, Kobe, Japan, and \\ ${ }^{6}$ Diabetes Branch, National Institutes of Health, Bethesda, Maryland, USA
}

\begin{abstract}
Summary. We analyzed single-stranded conformational polymorphisms to screen for mutations and polymorphisms in the insulin receptor gene in subjects with or without insulin resistance. Using this new technique, we demonstrated the existence of mutations in the insulin receptor gene which we had identified previously. In addition, a new mutation was found in exon 20 of the insulin receptor gene in a patient with moderate insulin resistance associated with morbid obesity, acanthosis nigricans, and polycystic ovary syndrome. The patient was heterozygous for a mutation substituting Leu (CTG) for Pro (CCG) at codon 1178. Pro ${ }^{1178}$ is a part of a characteristic sequence motif ( $D^{1150} \mathrm{~F}^{151} \mathrm{G}^{1152}--\mathrm{A}^{1177} \mathrm{P}^{1178} \mathrm{E}^{1179}$ ) common to many protein kinases. Analysis of single-stranded conformational polymorphisms was also used to estimate the frequency of a polymorphism at codon 1058 . The two codons
\end{abstract}

CAC (1058 His) and CAT (1058 His) both had a prevalence of $50 \%$ in 30 Japanese subjects. These data demonstrate that analysis of single-stranded conformational polymorphisms is a simple and sensitive screening method for mutations and polymorphisms in the insulin receptor gene in subjects with or without insulin resistance. Identification of a mutation in the insulin receptor gene in a patient with a moderate degree of insulin resistance associated with morbid obesity suggests that insulin receptor mutations may exist in patients with Type 2 (non-insulin-dependent) diabetes mellitus associated with a moderate degree of insulin resistance.

Key words: Hyperinsulinaemia, tyrosine kinase activity, Type 2 (non-insulin-dependent) diabetes mellitus, obesity, screening.
Mutations in the insulin receptor gene can cause insulin resistance and diabetes mellitus [1-17]. We have previously identified mutations in the insulin receptor gene in patients with genetic forms of extreme insulin resistance such as leprechaunism, the Rabson-Mendenhall syndrome, and type A extreme insulin resistance $[1,2,6,10$, $11,15-17]$. These mutations were originally identified by cDNA cloning $[2,3,6,8,9]$ and more recently by methods utilizing the polymerase chain reaction (PCR) and direct sequencing [10-12, 14, 15-17]. However, because these methods require determination of the entire protein coding sequence gene to identify base substitutions, there has been a need for more rapid and efficient techniques.

Recently, Orita et al. reported a new technique for analyzing single-stranded conformational polymorphisms (SSCP) in DNA amplified by PCR $[18,19]$. This method is based on the principle that the conformation of a single-stranded DNA molecule depends upon its nucleotide sequence. Even a point mutation can alter the conformation, causing a detectable shift in electrophoretic mobility. In the present study, we have demonstrated that PCR-SSCP analysis can detect variants in the nucleotide sequence of the insulin receptor gene. We successfully detected five mutations and polymorphisms previously identified in the insulin receptor gene. Upon screening five patients with mild and moderate degrees of insulin resistance using PCR-SSCP, we detected a new mutation of the insulin receptor gene in one patient with moderate insulin resistance and obesity.

\section{Subjects, materials and methods}

\section{Genomic DNA}

Genomic DNA derived from four patients $[2,6,8,10,11]$ with identified mutations in the insulin receptor gene was isolated from lymphoblast cell lines transformed by the Epstein-Barr virus using standard procedures as previously described [10]. Genomic DNA was also prepared from lymphocytes from venous blood of 35 additional subjects: seven normal control subjects, 23 patients with Type 2 (non-insulin-dependent) diabetes without known hyperinsulinaemia, and five patients with mild to moderate degrees of hyperinsulinaemia. The diagnosis of diabetes was based on the criteria set by the Japan Diabetic Society in 1982 [20]. Four of the five patients with mild to moderate degrees of hyperinsulinaemia had poly- 
Table 1. Pairs of primers for amplifying exons of the human insulin receptor gene

\begin{tabular}{cll}
\hline Exon & $\begin{array}{l}\text { Primer } \\
\text { Up Stream }(x-2) \\
\text { Down Stream }(x-1)\end{array}$ & $\begin{array}{l}\text { Size } \\
\text { of PCR } \\
\text { Products } \\
\text { (bp) }\end{array}$ \\
\hline $6(6-2)$ & 5'AGGCACGTAGCACTGAACA & 433 \\
$(6-1)$ & 5'-TGTAATGCACTTGAATCATGCTG & \\
$14(14-2)$ & 5'-TGGACACACTCCCAGATGTGCA & 276 \\
$(14-1)$ & 5'-ACCATGCTCAGTGCTAAGCA & \\
$16(16-2)$ & 5'-TCTGCTGGTAAGGGCTGCCA & 248 \\
$(16-1)$ & 5'-CTCACTCAATGGTGAAGGCA & \\
$17(17-2)$ & 5'-CCAAGGATGCTGTGTGTAGATAAG \\
$(17-1 A)$ & 5'-TCAGGAAAGCCAGCCCATGTC & 317 \\
$(17-1 B)$ & 5'-TGATGGCAGGTGAAGCCCTTC & 273 \\
$18(18-2)$ & 5'-CTGGTGAGTCGAATCACGGA & 214 \\
$(18-1)$ & 5'-AGCGGGTGCTTCCACCGAGTA & \\
$19(19-2)$ & 5'-GATCCCAGTGCTGCTGAAACAC & 285 \\
$(19-1)$ & 5'-ACGGCTCATTATAGACAACTTC & \\
$20(20-2)$ & 5'-AGGTTAAGAGCGTGTGAACCT & 208 \\
$(20-1)$ & 5'-GAATTCAAGCCCAGCGTCCAT & \\
$21(21-2)$ & 5'-TGTTACTACTATCAACTGTC & 291 \\
$(21-1)$ & 5'-ACCTGTAACATACAGCATGC & \\
\hline
\end{tabular}

$\mathrm{PCR}$, polymerase chain reaction; bp, base pairs

cystic ovary disease syndrome with fasting immunoreactive insulin levels ranging from $25 \mu \mathrm{U} / \mathrm{ml}$ to $97 \mu \mathrm{U} / \mathrm{ml}$. One of the four patients is morbidly obese (BMI $34.5 \mathrm{~kg} / \mathrm{m}^{2}$ ) and one of them is obese (BMI $28.5 \mathrm{~kg} / \mathrm{m}^{2}$ ) with acanthosis nigricans.

\section{Primers for PCR-mediated amplification of the insulin receptor gene}

Primers were chosen in the introns adjacent to each exon [21, 22] (Table 1). Two different sets of primers were used in the present study to amplify exon 17 ; the second set was chosen within the sequence of exon 17 to exclude the site of polymorphism commonly observed in the normal subjects [6,11]. For exons $6,14,16,18,19,20$, and 21 , single sets of primers were used.

The oligonucleotides used as primers were synthesized by the phosphoroamidite method with trityl in the DNA synthesizer and purified with oligonucleotide purification columns (Applied Biosystems Inc., Foster City, Calif, USA).

\section{PCR-SSCP analysis of the insulin receptor gene on genomic DNA}

Exons $6,14,16,17,18,19,20$ and 21 of the insulin receptor genes were amplified by PCR catalyzed by Taq DNA polymerase using genomic DNA as template and ${ }^{32} \mathrm{P}$-end-labelled oligonucleotides as primers $[10,11,23]$.

Following initial denaturation of DNA strands at $94^{\circ} \mathrm{C}$ for $5 \mathrm{~min}$, the reactions consisted of 25 cycles of denaturation at $94^{\circ} \mathrm{C}$ for $60 \mathrm{~s}$, annealing at $55^{\circ} \mathrm{C}$ for $60 \mathrm{~s}$, and extension at $70^{\circ} \mathrm{C}$ for $90 \mathrm{~s}[10,11,21$ 23]. The PCR products were diluted 1:10 with loading dye $(98 \%$ formamide, $20 \mathrm{mmol} / 1 \mathrm{EDTA}, 0.05 \%$ bromo-phenol-blue, $0.05 \%$ xylenecyanol), heated at $80^{\circ} \mathrm{C}$ for $5 \mathrm{~min}$, and $1 \mu \mathrm{l}$ of each sample was loaded onto a $5 \%$ polyacrylamide gel $(20 \times 40 \times 0.03 \mathrm{~cm}$, acrylamide: $N, N^{\prime}$ bis acrylamide $\left.=49: 1\right)$. Each sample was applied to four gels, two containing $10 \%$ glycerol and two without; one of each type of gel was subjected to electrophoresis at $4^{\circ} \mathrm{C}$ and one at room temperature at a constant power of $40 \mathrm{~W}$, completed in 2.5 to $4 \mathrm{~h}$ using laminar flow fans. Electrophoresis was performed in a Tris-borate buffer containing $45 \mathrm{mmol} / 1$ Tris-borate and $1 \mathrm{mmol} / 1$ EDTA. The gels were allowed to dry on filter paper (Whatman $3 \mathrm{~mm}$, Whatman International Ltd, Maidstone, UK) and then autoradiographed with $\mathrm{X}$-ray film using intensifying screens at $-70^{\circ} \mathrm{C}$ for $12-24 \mathrm{~h}[18,19]$.

\section{Direct sequencing of amplified genomic DNA}

The nucleotide sequence of amplified DNA was determined directly by the method of Kadowaki et al. [10,11].

\section{Results}

\section{Detection of a polymorphism in exon 17 in 30 subjects}

When ${ }^{32} \mathrm{P}$-labelled PCR products of exon 17 of the insulin receptor gene were separated by electrophoresis after heat denaturation, they migrated as two ${ }^{32} \mathrm{P}$-labelled bands as exemplified in lane 1 from a control subject (Fig. 1a,b). The upper and lower bands represent two complementary single-strand DNAs. As shown in lane 2 in Figure 1 a, both upper and lower ${ }^{32} \mathrm{P}$-labelled bands from another control subject migrate differently as compared to lane 1. Direct sequencing analysis of the two PCR products revealed a single nucleotide difference CAT (lane 1 and 3, positions $A$ and $C$ ) vs CAC (lane 2 and 4 , positions $B$ and $D$ ) at codon 1058 both encoding histidine [6, 11]. As shown in lane 5-7 (Fig. 1 a), ${ }^{32}$ P-labelled

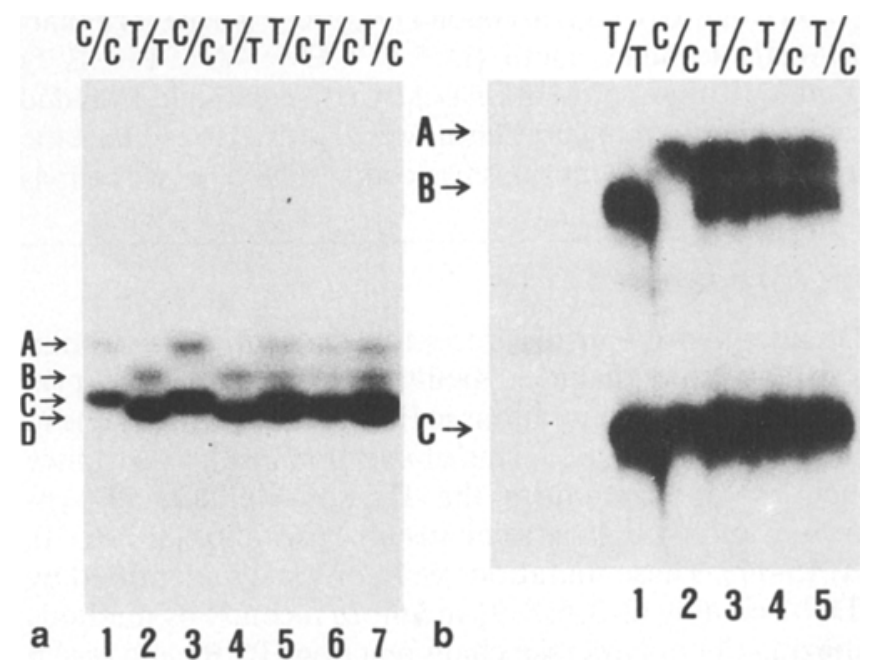

Fig. 1a,b. A polymorphism in exon 17 detected by neutral polyacrylamide gel electrophoresis without (a) and with (b) $10 \%$ glycerol at room temperature. a Two patterns of the polymerase chain reaction (PCR) products in single-stranded conformational polymorphisms analysis from two normal subjects are shown in lanes 1 and 2 . Analysis by direct sequencing of these two PCR products revealed a single nucleotide difference CAC (lane 1, A) vs CAT (lane 2, B) at codon 1058 both encoding histidine $(6,11)$. The subjects in lane 1 and 3 are homozygous for CAC and the subjects in lane 2 and 4 are homozygous for CAT. Subjects shown in lane 5-7 were heterozygous for CAC and CAT. b The subject in lane 1 is homozygous for CAT and the subject in lane 2 is homozygous for CAC. The order of the samples in lane 1 and lane 2 is reversed as compared to that in Figure $1 \mathrm{a}$. Samples shown in lane 3-5 are heterozygous for $\mathrm{CAC}$ and CAT 


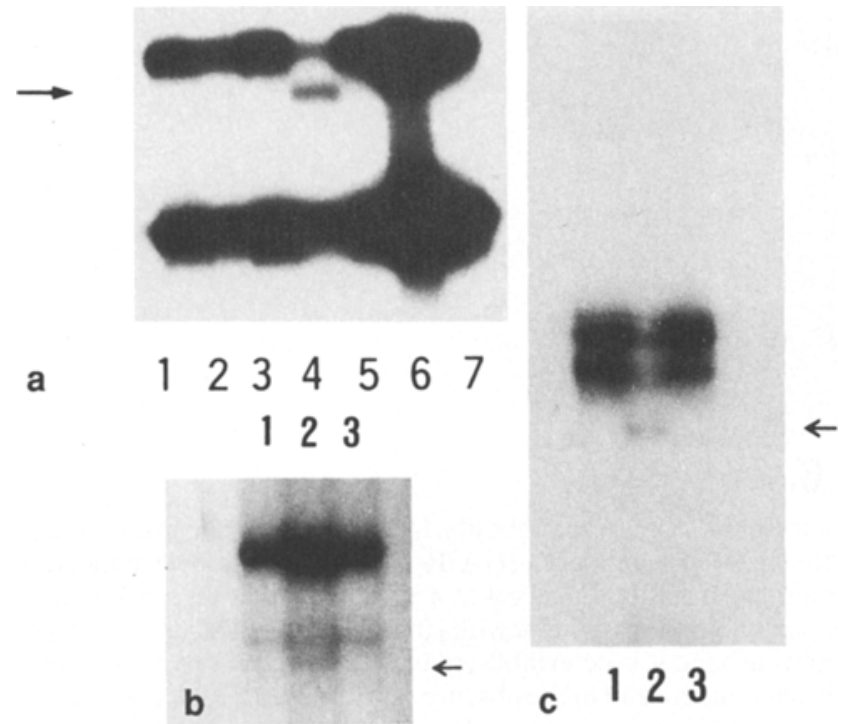

Fig. 2. a Detection of known mutations using the second set of primers in exon 17 (17-1B, 17-2) by polymerase chain reaction-singlestranded conformational polymorphisms (PCR-SSCP) analysis. The site of polymorphism at codon 1058 was excluded from the PCR product. In lanes $1,2,3,5,6$ and 7, normal control subjects showed only two bands, whereas in lane 4 , which is the sample from a patient with type A syndrome (6), two distinct upper bands were detected. This result is consistent with the fact that this patient has a heterozygous mutation substituting Val for Gly at codon 1008 in exon 17(6) b Detection of a known mutation in exon 6 by PCR-SSCP. Under the conditions with $10 \%$ glycerol at room temperature, in lane 1 and 3 , normal control subjects showed only two bands. In lane 2 , two lower bands were observed in the sample from patient leprechaunism/Ark-1 who is heterozygous for a mutation substituting Glu for Lys at codon 460 in exon 6(2) c Detection of a known mutation in exon 14 by PCR-SSCP. In lanes 1 and 3, normal control subjects showed only two bands. In lane 2 , one of the two upper bands ran slower than those in lane 1 and 3 under the conditions without glycerol at room temperature. The subject in lane 2, was from patient leprechaunism/Minn-1 who was heterozygous for a mutation substituting a stop codon for Arg at codon 897 in exon 14(10)

PCR products from additional control subjects migrated at positions A, B, C, and D suggesting that these subjects' were heterozygous for both CAT and CAC at this position when detected by polyacrylamide gel electrophoresis without glycerol at room temperature. This was confirmed by PCR-direct sequencing (data not shown). PCRSSCP analysis of the same PCR products were carried out under different conditions (room temperature, $10 \%$ glycerol (+)) (Fig. 1b). Upper bands again migrated at two distinct positions (A and $B$ ), while lower bands migrated at only one position $(\mathrm{C})$. This suggests that one nucleotide change at this position affects the electrophoretic mobility of only one of these two complementary singlestrand DNAs under these conditions.

Based upon the results of PCR-SSCP, we have calculated the frequency of both alleles. The allele frequency of CAC and CAT at position 1058 was estimated at $50 \%: 50 \%$, respectively, in 30 Japanese subjects. However, there was no difference in the allele frequency between the normal subjects and the subjects with Type 2 diabetes (data not shown).
Detection of known mutations in the insulin receptor gene

The presence of three patterns due to the polymorphism in exon 17 interferred with unequivocal detection of mutations in other regions in this amplified fragment (data not shown). When primers within the sequence of exon 17 were chosen to exclude the site of the polymorphism, we were able to detect the mutations in exon 17 which had been identified in the patients with extreme insulin resistance. Using primers 17-1B and 17-2 (Table 1), we applied the SSCP method to analyse genomic DNA from a patient with type A extreme insulin resistance [6] and a patient with the Rabson-Mendenhall syndrome [11]. When this set of primers was used, the site of polymorphism at codon 1058 was excluded, and only two bands were observed in the sample from normal control subjects (Fig. 2a, lanes 1-3, 5,6). However, in one of these samples, two distinct upper bands were detected (Fig. 2a, lane 4). This is consistent with the fact that the patient was previously shown to be heterozygous for a mutation substituting Val for Gly at codon 1008 in exon 17 [6]. A heterozygous mutation in exon 17 substituting a stop codon for Arg at codon 1000 that we have previously identified [11] was also detected by SSCP under identical conditions (data not shown). Thus, both of the two mutations of exon 17 previously identified were clearly detected under the conditions $4^{\circ} \mathrm{C}$ without glycerol at. We extended PCRSSCP analysis to other exons of the insulin receptor gene. In exon 6, under the conditions with $10 \%$ glycerol at room temperature, two lower bands were observed in the sample taken from patient leprechaunism/Ark-1 who is heterozygous for a missense mutation substituting Glu for Lys at codon 460 in exon 6 (Fig. 2 b) [2]. In exon 14, under the conditions without glycerol at room temperature, compared with control DNA, one of the two upper bands ran slower in the sample isolated from a patient who was heterozygous for a mutation substituting a stop codon for Arg at codon 897 in exon 14 (Fig. 2c) [10]. Thus, the SSCP method successfully detected four previously described mutations in exons 6,14, and 17 of the insulin receptor gene of patients with type A extreme insulin resistance, the Rabson-Mendenhall syndrome, and leprechaunism.

\section{Screening subjects with Type 2 diabetes and insulin resistance for variant sequence in the tyrosine kinase domain of the insulin receptor gene}

Genomic DNA was screened for mutations in the tyrosine kinase domain of the insulin receptor gene (exons 16-21) of five patients with mild to moderate insulin resistance and 23 patients with Type 2 diabetes without known hyperinsulinaemia. Electrophoresis was carried out under all four experimental conditions. In analysing amplified DNA from exon 20 of a patient with amenorrhoea, obesity, acanthosis nigricans, hypertrichosis, and moderate degree of insulin resistance, we observed that one of the two lower bands migrated more slowly under the conditions without $10 \%$ glycerol at $4{ }^{\circ} \mathrm{C}$, in the analysis of exon 20 of the insulin receptor gene (Fig. 3 a, lane 6). Under the conditions with $10 \%$ glycerol at $4{ }^{\circ} \mathrm{C}$, an aber- 


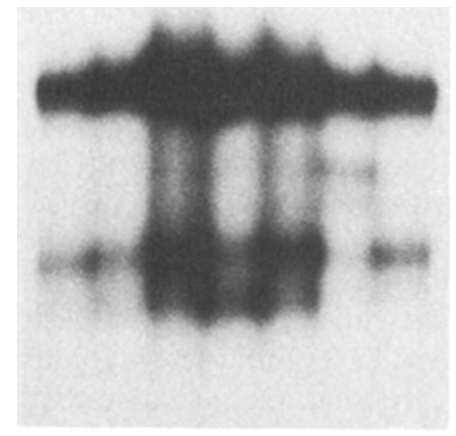

a) 23345667

Fig.3a,b. Genomic DNA screening for mutations in the insulin receptor gene in patients with mild to moderate insulin resistance. Analysis of exon 20 in the insulin receptor gene by polymerase chain reaction-single-stranded conformational polymorphisms (PCRSSCP) analysis was performed in patients with mild to moderate insulin resistance (lanes 1-7). The genomic DNA sample in lane 6 was

rantly migrating band was also detected in this sample (Fig. 3b, lane 6). Under the conditions at room temperature in the absence or presence of $10 \%$ glycerol, we could still discern aberrantly migrating bands in samples from this patient, although alterations in electrophoretic mobility were less evident than at $4^{\circ} \mathrm{C}$ (data not shown).

We observed minor faint bands with all of the samples only under the conditions without glycerol at $4^{\circ} \mathrm{C}$. The relative intensities and the mobilities of these bands

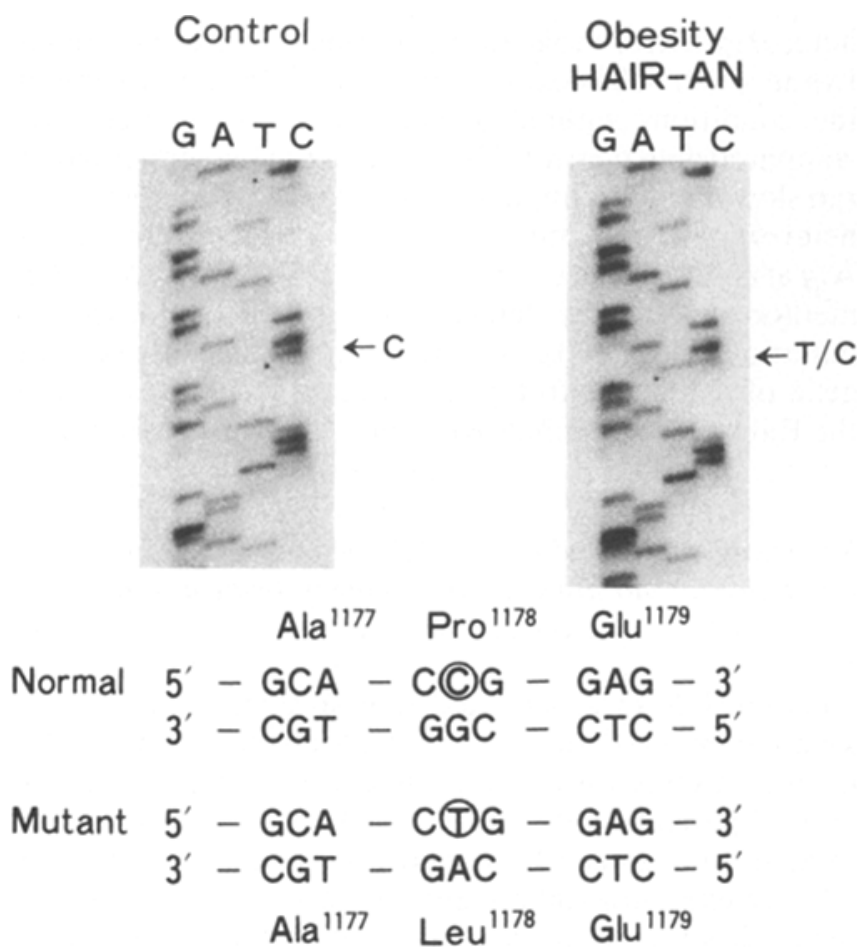

\section{Obesity HAIR-AN}

Fig. 4. Polymerase chain reaction direct sequencing of exon 20 in the insulin receptor gene of the patient with an abnormal singlestranded conformational polymorphisms electrophoretic pattern in Figure 3. The nucleotide sequence of amplified exon 20 of the insulin receptor gene was determined directly $[10,11]$. The patient is heterozygous for a mutation substituting $\mathrm{Leu}(\mathrm{CT} G)$ for Pro $(\mathrm{CC} G)$ at codon 1178 in exon 20 taken from a women with obesity, hyperandrogenism, insulin resistance, acanthosis nigricans (HAIR-AN) and the sample subject to conditions a without glycerol at $4^{\circ} \mathrm{C}$ b with $10 \%$ glycerol at $4^{\circ} \mathrm{C}$. Under conditions without or with $10 \%$ glycerol at $4{ }^{\circ} \mathrm{C}$, an aberrantly migrating band was detectable in lane 4 , whereas it was not obvious at room temperature in the absence or presence of $10 \%$ glycerol

depended on the conditions of electrophoresis. We thought that these bands were different conformations of the same sequence sometimes occurring under certain conditions [19].

Independently, by directly determining the sequence of amplified DNA, we demonstrated that this patient is heterozygous for a mutation substituting Leu (CTG) for Pro (CCG) at codon 1178 in exon 20 (Fig.4).

\section{Discussion}

Predisposition to Type 2 diabetes may partly be due to mutations in the insulin receptor [1]. At least 25 point mutations in the insulin receptor gene have been identified in patients with genetic forms of extreme insulin resistance [2-17]. Many of these mutations have been identified by direct sequencing of PCR products after amplifying each of the 22 exons of the insulin receptor gene using patients' genomic DNA as templates [10-12,14-17]. However, this technique is quite labor-intensive and time-consuming. Therefore, large-scale screening for mutations in the insulin receptor gene has not been possible.

In recent years, several new techniques for detecting mutations have been developed. These include chemical mismatch cleavage [24] and ribonuclease cleavage [25, 26] at mismatches and denaturing gradient gel electrophoresis (DGGE). However, the sensitivity of cleavage methods has often been reported as unsatisfactory [2426]. To optimize the sensitivity of the DGGE technique, it is necessary to attach a 40 base pair GC-rich fragment (GC clamp) at the end of one of the primers [27, 28].

In 1989, Orita et al. reported a new simple technique referred to as PCR-SSCP based upon the principle that the conformation and electrophoretic mobility in the nondenaturing gel of single-strand DNA depends exquisitely upon its nucleotide sequence $[18,19]$. PCR-SSCP has recently been used to screen for base substitutions in other genetic diseases such as neurofibromatosis type 1 [29] or cystic fibrosis [30]. In the present study, we were able to detect all four mutations and the polymorphisms tested 
Table 2. Detectability of mutations and polymorphisms in the human insulin receptor gene by single-stranded conformational polymorphisms under four conditions

\begin{tabular}{|c|c|c|c|c|c|c|c|c|c|c|}
\hline \multirow[t]{2}{*}{ Exon } & \multirow[t]{2}{*}{ Patient } & \multicolumn{3}{|c|}{ Codon } & \multirow[t]{2}{*}{ Primers } & \multirow{2}{*}{$\begin{array}{l}\text { Length } \\
\text { (bp) }\end{array}$} & \multirow{2}{*}{$\begin{array}{l}\text { RT } \\
\text { G } \\
(-)\end{array}$} & \multirow{2}{*}{$\begin{array}{l}\mathrm{RT} \\
10 \% \mathrm{G} \\
(+)\end{array}$} & \multirow{2}{*}{$\begin{array}{l}4^{\circ} \mathrm{C} \\
\mathrm{G} \\
(-)\end{array}$} & \multirow{2}{*}{$\begin{array}{l}4^{\circ} \mathrm{C} \\
10 \% \mathrm{G} \\
(+)\end{array}$} \\
\hline & & $\#$ & wild type & variant & & & & & & \\
\hline 17 & Normal & 1058 & $\begin{array}{c}\mathrm{CAC} \\
(\mathrm{CAT})\end{array}$ & $\begin{array}{l}\text { CAT } \\
(\mathrm{CAC})\end{array}$ & $\begin{array}{l}17-1 \mathrm{~A} \\
17-2\end{array}$ & 317 & + & + & - & - \\
\hline 17 & $\begin{array}{l}\text { Rabson- } \\
\text { Mendenhall }\end{array}$ & 1000 & $C G A$ & $T G \mathrm{~A}$ & $\begin{array}{l}17-1 B \\
17-2\end{array}$ & 273 & - & - & + & + \\
\hline 6 & leprechaunism & 460 & $A \mathrm{AG}$ & $G \mathrm{AG}$ & $\begin{array}{l}6-1 \\
6-2\end{array}$ & 433 & - & + & + & + \\
\hline 14 & leprechaunism & 897 & $C G A$ & $T \mathrm{GA}$ & $\begin{array}{l}14-1 \\
14-2\end{array}$ & 276 & + & - & - & - \\
\hline 20 & $\begin{array}{l}\text { Obesity } \\
\text { HAIR-AN }\end{array}$ & 1178 & $\mathrm{CCG}$ & $\mathrm{CTG}$ & $\begin{array}{l}20-1 \\
20-2\end{array}$ & 208 & - & - & + & + \\
\hline
\end{tabular}

RT, room temperature; bp, base pairs; HAIR-AN, hyperandrogenism, insulin resistance, acanthosis nigricans; G( - ), without glycerol; $10 \%$ $\mathrm{G}(+)$, containing $10 \%$ glycerol; + +, remarkably detectable; +, detectable; - , not detectable

that previously had been identified by either cDNA cloning or direct sequencing of the insulin receptor gene. Using the PCR-SSCP method, the entire procedure including exposure time can be completed within $24 \mathrm{~h}$, and no special equipment is required. Thus, the PCR-SSCP method is a simple, fast, and sensitive method for detecting mutations in the human insulin receptor gene.

We performed electrophoresis of SSCP under four conditions, i. e. at room temperature or $4{ }^{\circ} \mathrm{C}$ in the presence or absence of $10 \%$ glycerol. The results of the present study suggest that these conditions may affect the sensitivity of the technique differently depending upon the various base substitutions. Thus, although some mutations were preferentially detected under one or two of these conditions, other mutations were preferentially detected under other conditions (Table 2). Therefore, we suggest that it is important to perform PCR-SSCP under all four conditions to maximize the sensitivity in detecting mutations. In addition, as shown in the analysis of mutations in exon 17 , choosing oligonucleotide primers to exclude the segment of genomic DNA containing frequent polymorphisms increases the ability of PCR-SSCP to detect mutations in this region.

While screening patients with mild to moderate degrees of insulin resistance using PCR-SSCP, a new mutation was detected in a patient who is a 14-year-old female with obesity, acanthosis nigricans and hyperandrogenism causing polycystic ovary disease syndrome, hypertrichosis, and amenorrhoea. Because of her obesity, this patient differs from lean patients with classical type A insulin resistance [31]. The pattern of her oral glucose tolerance test was within normal range. The fasting insulin level was $93 \mu \mathrm{U} / \mathrm{ml}$ and the fasting blood glucose level was $4.3 \mathrm{mmol} / 1$. Previously, it was suspected that insulin resistance and other clinical features in obese patients with the syndrome of the hyperandrogenism, insulin resistance, and acanthosis nigricans (HAIR-AN) are due to obesity rather than mutations in the insulin receptor gene. Furthermore, this patient's insulin resistance is less than that of some patients with the classified type A syndrome [8].
For example, there was a clear hypoglycaemic response, although subnormal, when the patient was given $0.1 \mathrm{U} / \mathrm{kg}$ insulin intravenously.

Substitution of Leu (CTG) for Pro (CCG) may be a functionally relevant mutation. First, substitution of leucine for proline is not a conservative substitution. Second, Pro $^{1178}$ is a part of characteristic sequence motif $\left(D^{1150} \mathrm{~F}^{1151} \mathrm{G}^{152}\right.$--- $\left.\mathrm{A}^{1177} \mathrm{P}^{1178} \mathrm{E}^{1179}\right)$ common to many protein kinases [32]. Five missense mutations in the cytoplasmic domain of the insulin receptor gene have been described which decreases the receptor's tyrosine kinase activity [2, 4-6, 15]. Two of these mutations $\left(\mathrm{Arg}^{993} \rightarrow \mathrm{Gln}[4], \mathrm{Gly}^{1008} \rightarrow \mathrm{Val}[6]\right)$ are in the region of the ATP binding domain and three of these $\left(\mathrm{Thr}^{1134} \rightarrow \mathrm{Ala}[2]\right.$, $\left.\mathrm{Ile}^{1153} \rightarrow \mathrm{Met}[15], \operatorname{Trp}^{1200} \rightarrow \mathrm{Ser}[5]\right)$ cluster near the autophosphorylation sites $\left(\mathrm{Tyr}^{1158}, \mathrm{Tyr}^{1162}, \mathrm{Tyr}^{1163}\right)$. The Pro $^{1178} \rightarrow$ Leu mutation is also located near the autophosphorylation sites. These results are consistent with the notion that these two regions of the cytoplasmic domain of the insulin receptor gene are fundamental for receptor function. The actual functional impact of this mutation is currently being investigated in this laboratory.

Identification of a missense mutation in the insulin receptor gene in this type of patient raises the possibility that mutations in the insulin receptor gene may be more common than was originally supposed in patients with a mild to moderate degrees of insulin resistance such as obesity, acanthosis nigricans, polycystic ovary syndrome and also Type 2 diabetes [33]. Using PCR-SSCP as described in the present study, it will be possible to investigate a much large number of patients than have been studied to date. Eventually, it should become possible to estimate the frequency of mutations in the insulin receptor gene, and to determine whether mutations in the insulin receptor gene contribute to the pathogenesis of common disease such as Type 2 diabetes.

Acknowledgements. We thank Drs. O.Isozaki and T.Tsushima (Tokyo Women's Medical College) for isolating genomic DNA from the patient. We also thank Dr. K. Hayashi (National Cancer Center Research Institute), Dr. O. Koshio (Institute for Diabetes Care and 
Research, Asahi Life Foundation), Drs. K. Tobe, H.Tamemoto, Y.Kaburagi, K. Ueki, M. Kishimoto and K. Muraoka (The Third Department of Internal Medicine, Faculty of Medicine, University of Tokyo) for help and useful discussions. This work was supported by the Juvenile Diabetes Foundation International research grant 190831 to T. Kadowaki.

\section{References}

1. Taylor SI, Kadowaki T, Kadowaki H, Accili D, Cama A, McKeon $\mathrm{C}(1990)$ Mutations in the insulin receptor gene in insulin resistant patients. Diab Care 13:257-279

2. Kadowaki T, Bevins CL, Cama A et al. (1988) Two mutant alleles of the insulin receptor gene in a patient with extreme insulin resistance. Science 240: 787-790

3. Yoshimasa Y, Seino S, Whittaker J et al. (1988) Insulin-resistant diabetes due to a point mutation that prevents insulin proreceptor processing. Science 240: 784-787

4. Kobayashi M, Sasaoka T, Takata Y et al. (1988) Insulin resistance by unprocessed insulin proreceptors - point mutation at the cleavage site. Biochem Biophys Res Comm 153: 657-663

5. Moller DE, Flier JS (1988) Detection of an alteration in the insulin-receptor gene in a patient with insulin resistance, acanthosis nigricans, and the polycystic ovary syndrome (type A insulin resistance). N Engl J Med 319:1526-1529

6. Odawara M, Kadowaki T, Yamamoto R et al. (1989) Human diabetes associated with a mutation in the tyrosine kinase domain of the insulin receptor. Science 245: 66-68

7. Taira M, Taira M, Hashimoto N et al. (1989) Human diabetes associated with a deletion of the tyrosine kinase domain of the insulin receptor. Science 245: 63-66

8. Accili D, Frapier C, Mosthaf L et al. (1989) A mutation in the insulin receptor gene that impairs transport of the receptor to the plasma membrane and causes insulin resistant diabetes. EMBO J 8: 2509-2517

9. Klinkhamer MP, Groen NA, van der Zon GCM et al. (1989) A leucine-to-proline mutation in the insulin receptor in a family with insulin resistance. EMBO J 8:2503-2507

10. Kadowaki T, Kadowaki H, Taylor SI (1990) A nonsense mutation causing decreased levels of insulin receptor mRNA: detection by a simplified technique for direct sequencing of genomic DNA amplified by polymerase chain reaction. Proc Natl Acad Sci USA 87: 658-662

11. Kadowaki T, Kadowaki H, Rechler MM et al. (1990) Five mutant alleles of the insulin receptor gene in patients with genetic forms of insulin resistance. J Clin Invest 86: 254-264

12. Moller DF, Yokota A, White MF, Pazianos AG, Flier JS (1990) A naturally occuring mutation of insulin receptor Ala ${ }^{134}$ impairs tyrosine kinase function and is associated with dominantly inherited insulin resistance. J Biol Chem 265: 14979-14985

13. Shimada F, Taira M, Suzuki Y et al. (1990) Insulin-resistant diabetes associated with partial deletion of insulin receptor gene. Lancet 335: 1179-1181

14. Kusari J, Takata Y, Hatada E, Freidenberg G, Kolterman O, Olefsky JM (1991) Insulin resistance and diabetes due to different mutations in the tyrosine kinase domain of both insulin receptor gene alleles. J Biol Chem 266:5260-5267

15. Cama A, Sierra ML, Ottini Letal. (1991) A mutation in the tyrosine kinase domain of the insulin receptor associated with insulin resistance in an obese woman. J Clin Endocrinol Metab 73: 894901

16. Imano E, Kadowaki H, Kadowaki T et al. (1991) Two patients with insulin resistance due to decrease levels of insulin receptor mRNA. Diabetes 40: 548-557
17. Kadowaki T, Kadowaki H, Ando A et al. (1991) Two mutant alleles of the insulin receptor gene in insulin resistant patients. Endocrinology 128 [Suppl]: 310 (Abstract)

18. Orita M, Iwahana H, Kanazawa H, Hayashi K, Sekiya T (1989) Detection of polymorphisms of human DNA by gel electrophoresis as single-strand conformation polymorphisms. Proc Natl Acad Sci USA 86: 2766-2770

19. Orita M, Suzuki Y, Sekiya T, Hayashi K (1989) Rapid and sensitive detection of point mutations and DNA polymorphisms using the polymerase chain reaction. Genomics 5: 874-879

20. Japan Diabetic Society Expert Committee Report (1982) Classification and diagnosis of diabetes mellitus. J Jpn Diabetic Soc 25: 859-866

21. Seino S, Seino M, Nishi S, Bell GI (1989) Structure of the human insulin receptor gene and characterization of its promoter. Proc Natl Acad Sci USA 86: 114-118

22. Seino S, Seino M, Bell GI (1990) Human insulin receptor gene: partial sequence and amplification of exons using the polymerase chain reaction. Diabetes 39: 123-128

23. Saiki RK, Scharf S, Faloona F et al. (1985) Enzymatic amplification of $\beta$-globulin genomic sequences and restriction site analysis for diagnosis of sickle cell anemia. Science 230: 1350-1354

24. Grompe M, Muzny DM, Caskey CT (1989) Scanning detection of mutations in human ornithine transcarbamoylase by chemical mismatch cleavage. Proc Natl Acad Sci USA 86: 5888-5892

25. Myers RM, Larin Z, Maniatis T (1985) Detection of single base substitutions by ribonuclease cleavage at mismatches in RNA: DNA duplex. Science 230: 1242-1246

26. Landegren U, Kaiser R, Caskey CT, Hood L (1988) DNA diagnostics-molecular techniques and automation. Science 242: 229 237

27. Sheffield VC, Cox DR, Lerman LS, Myers RM (1989) Attachment of a 40-base-pair $\mathrm{G}+\mathrm{C}$-rich sequence (GC-clamp) to genomic DNA fragments by the polymerase chain reaction results in improved detection of single-base changes. Proc Natl Acad Sci USA 86: 232-236

28. Myers RM, Fischer SG, Maniatis T, Lerman LS (1985) Modification of the melting properties of duplex DNA by attachment of a GC-rich DNA sequence as determined by denaturing grandient gel electrophoresis. Nucleic Acid Res 13:3111-3129

29. Cawthon RM, Weiss R, Xu G et al. (1990) A major segment of the neurofibromatosis type 1 gene: cDNA sequence, genomic structure, and point mutations. Cell 62: 193-201

30. Dean M, White MB, Amos J et al. (1990) Multiple mutations in highly conserved residues are found in mildly affected cystic fibrosis patients. Cell 61: 863-870

31. Kahn CR, Flier JS, Bar RS et al. (1976) The syndromes of insulin resistance and acanthosis nigricans. Insulin-receptor disorders in man. N Engl J Med 294: 739-745

32. Hanks SK, Quinn AM, Hunter T (1988) The protein kinase family: conserved features and deduced phylogeny of the catalytic domains. Science 241: 42-52

33. O'Rahilly S, Choi WH, Patel P, Turner RC, Flier JS, Moller DE (1991) Detection of mutations in insulin-receptor gene in NIDDM patients by analysis of single-stranded conformation polymorphisms. Diabetes 40: 777-782

Received: 13 August 1991

and in revised form: 5 November 1991

Dr. T. Kadowaki

The Third Department of Internal Medicine

Faculty of Medicine

University of Tokyo

Hongo 7-3-1 Bunkyo-ku

Tokyo 113

Japan 